\title{
Intercultural Competence in Practice: Internship Abroad in the B.A. Program "International Information Management" at the Hildesheim University Foundation
}

\author{
Olga Mennecke \\ Hildesheim University Foundation, Lübecker Str., 3, 31141 Hildesheim, Germany
}

\begin{abstract}
This article outlines the relationship between the internship abroad and intercultural competence, which has become a key qualification in the context of globalized higher education. The aspects of the intercultural-orientated curriculum and its challenges are described based on the concrete example of the internship implementation.
\end{abstract}

\section{Introduction}

In the last decades and especially after the Bologna declaration, which set the framework for the common European higher education, many European degree programs have implemented one or two-terms study or internship abroad. The B.A. program "International information management" (IIM) at the Hildesheim University Foundation, in which students are given a choice between a semester abroad or a minimum 12-week internship abroad, is no exception there. These two options are intended, on the one hand, to intensify student's research-oriented specialist knowledge in the field of information management, and on the other hand to strengthen and reflect on intercultural competence through a stay abroad.

This article intends not only to continue the theoretical discussion on the confluence of internships abroad and the development of students' intercultural competence but also to show its successful practical implementation. First, the theoretical framework related to intercultural competence as one of the key competencies in the globalized world will be outlined. So, it seems to be that more disappointing that despite the understanding that intercultural competence should be strengthened during the university studies and international mobility programs for students, the internship structural implementation in the curriculum is often deficient and, as practice shows, associated with prejudices about a greater effort on the part of students. In contrast to the semester abroad, thus, an internship abroad still plays a rather subordinate role in the academic context. The procedure of the curriculum internship implementation within the Bachelor program "International Information Management" at the Hildesheim University Foundation that motivates students to start their first professional experiences abroad simultaneously undergoing a significant process of refinement of their intercultural competencies will be disclosed below. This concept of merging an internship with the enhancement of intercultural competence, which 
reflects the orientations of the European higher education, can be successfully applied in many other graduate programs as well.

\section{The concept of intercultural competence as a theoretical construct}

It is challenging to find another issue discussed so often in the last few years than intercultural competence. After all the countless attempts to define and locate it anew, there seems to be at least an abstract theoretical consensus, that intercultural competence is an indispensable and fundamental attribute. In the academic field as well as in business and the job market, intercultural competence has become a so-called core - or key-qualification to strive for [1]. Evidently, the comprehensive definition of intercultural competence requires touching on many areas - cultural, anthropological, psychological, linguistic, etc., which is not possible within the scope of this article. Often, the construct of intercultural competence is simplified and described as the ability to interact appropriately in intercultural contexts, in which certain cultural "rules" are expected to follow and to be respected considering a certain socio-political framework [2]. Furthermore, intercultural competence is presented as a multidimensional construct of affective, cognitive, and behavioral categories [3].

Some concepts define intercultural competence as learned problem-solving ability bundled with cultural and environmental awareness [4]. One important aspect of this definition is the significance of self-responsibility which is crucial for the autonomous learning process based on self-organization and self-directing as given in the European educational context [5]. Adopting this aspect of self-responsibility for the concept of intercultural competence makes it clear, that the learning process should be conceptualized in a way to provide students with strategies for overcoming problems in an intercultural field. Accordingly, German theorists often subordinate intercultural competence to the concept of action competence ("Handlungskompetenz" as an ability of acting and making decisions self-directedly) [6,7].

Thus, keeping all these aspects in mind, it would be beneficial for both universities and students, if intercultural competence were to be treated as a variety of abilities that enables an individual to interact with culturally different counterparts delicately and solve tasks reflectively following the given situational interculturality [7]. But no matter which definition one may favor, the long-term nature of the intercultural competence formation process can be considered as one of its main characteristics, which makes it a lengthy and successive one.

\section{Implementing Interculturality}

According to a survey conducted by the German Academic Exchange Service in 2011, which examined the view of German companies on the international experience of Bachelor and Master graduates, the international experience of job candidates is highly valued by companies and is seen as an advantage when hiring them [8]. To follow this internationalization trend, universities are trying to expand student mobility programs and adapt their study courses to them to improve the important aspect of international reputation. However, what aspects should be taken in mind within the intercultural-oriented curriculum without creating a gap between theoretical concepts of interculturality and educational practice?

If students decide for an internship abroad, bureaucratic routines often play a predominant role during the preparation phase, which has to be done besides actual academic tasks, so that students hardly have the time capacity to attend one or more 
workshops or training on intercultural competence. Thus, the complex process of intercultural learning is only barely touched upon or not mentioned at all. However, it would be crucial to foster the perception of intercultural encounters, which is necessary for the constitution of intercultural knowledge patterns. The goal of intercultural learning is that these knowledge patterns trigger such actions that positively influence intercultural experiences. This moment would mean the transformation of the knowledge and the action patterns into intercultural competence [9]. Such theoretical concepts of intercultural learning have to be sufficiently elaborated in the preliminary phase.

The main phase of the internship abroad, which consists of everyday tasks or longer project work, depending on the chosen company, is mentored by a supervisor. Support in terms of intercultural competence is unfortunately lacking here. Back at the university, students evaluate their major and development process during the internship abroad by writing a report in the final phase. Ideally, forums with guest contributions from former interns should be integrated into the curriculum. That would be helpful both for themselves concerning the supported self-reflection of their intercultural experiences but also for the prospective interns in the preparation phase.

\section{Embedding of the Internship Abroad in the B.A. program "International Information Management" at the Hildesheim University}

In the Bachelor program "International Information Management" at the Hildesheim University internship abroad can be chosen by fifth-semester students as an alternative to one-term study abroad. The fifth semester is only a recommendation on the part of the study regulations, as it is assumed that by then students have acquired enough expertise and have determined their interests so that they can prioritize a certain practical direction and find an internship according to their preferences. The process of internship search, as well as the accommodation search, is mostly done on one's own, the internship coordinator advises students in the initial phase and, if needed, provides a list with the pool of foreign companies where former IIM-students have already had their internships, but most students do their own motivated search. This already involves engaging the action competencies that are important for a successful application process. Three aspects have to be considered while searching for an internship:

a)relation to contents of the study program (the possible internship tasks can be very diverse:

- software development and project management

- development of internet applications

- activities in the field of usability

- consulting and software ergonomics

- projects in online marketing and corporate communication

b)international field of the company should be present through partners or customers

c) the internship communication, which should take place in a foreign language (so it can be excluded that students choose German companies abroad).

The last two aspects are crucial for the further development of intercultural competence. If the requirements on the part of the university coincide with the potential internship position, an internship contract can be signed. It must be a full-time internship that should last at least 12 weeks. Upon agreement with the internship site, students can extend the duration of the internship. During the internship, it is recommended to write down daily tasks to facilitate the writing of the compulsory internship report. The report should inform about the internship organization, as well as a detailed description of the tasks performed. 
Also, there should be a brief account of the experience gained, as well as a critical evaluation and reflection of the internship, especially concerning the content of the study and intercultural competence gained during the internship.

So, how do IIM-students evaluate the impact of the internship abroad on their intercultural competence according to their reports? To determine the impact of the internship abroad on intercultural competence, 25 reports from 2018 and 2019 were randomly chosen and analyzed in terms of student self-evaluation of their intercultural competence before and after the internship abroad. The way students describe their internship experience makes it obvious that it is considered extremely beneficial. The table below shows the categories mentioned in the IIM-students' reports concerning their selfreflection of intercultural competence:

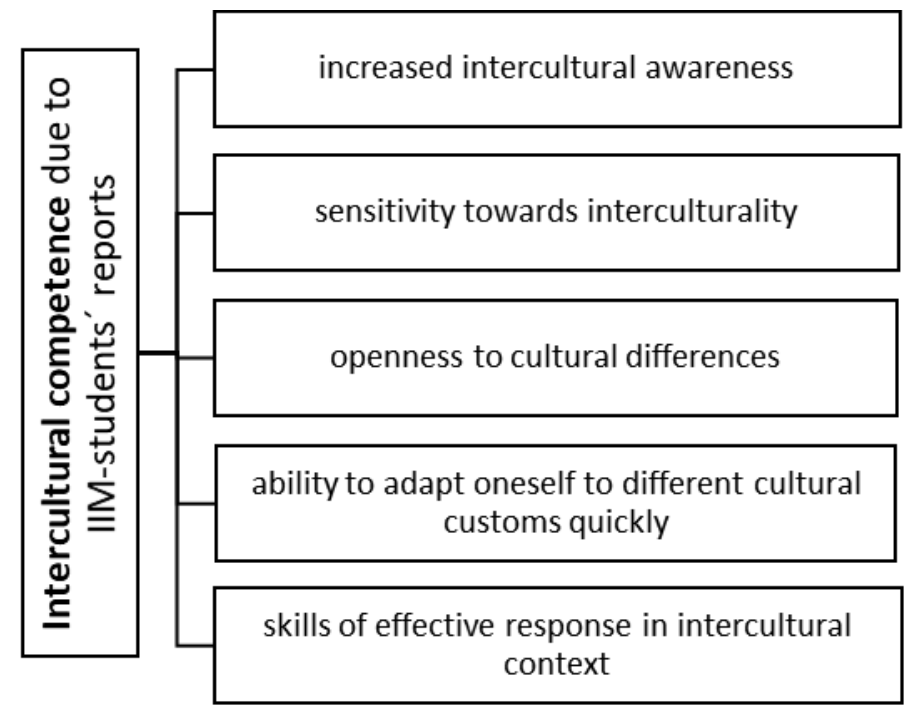

Fig. 1: Categories of intercultural competence according to students' internship reports

All students rate their intercultural competence after completing the internship period of at least 12-weeks significantly better than before. Although some of the students have taken advantage of the training offered by the International Office at the University of Hildesheim, aiming to prepare students for short- or long-termed academic stays abroad, they report feeling insecure about having sufficient intercultural skills before starting the internship. This insecure state seems to improve with the advancing duration of the internship: the longer the stay abroad, the more aware students become of their intercultural skills (some students report positive tendencies concerning intercultural awareness already after 2 weeks, but most of them need 4 to 6 weeks). Returning to the structural embedding of the internship abroad in the curriculum, it should be finally mentioned that because of the lengthy application process and the preparatory measures as well as for the actual internship tasks, IIM-students receive 25 credit points and for the summary of the report further 5 credit points.

\section{Conclusion}

This short analysis of the students' self-evaluated interculturality within their internship reports provides a further indication of the enormous importance of the internship abroad for the development of intercultural competence. According to these self-evaluations, different languages and communication patterns, deviating expectations from the 
counterpart and culturally conditioned interpretation habits are among the cultural diversities that students encounter while abroad. The theoretical considerations on intercultural competence outlined here can be adopted as an example of the practical implementation of the interculturally oriented curriculum to advance the further development of intercultural skills of students during their stays abroad. It is my view as the author and at the same time as the IIM internship coordinator, that to realize students' potentials in intercultural competence, generally, a critical view on the university as an institution and its' educational goals in the context of internationalization is needed. In practice, the first meaningful measures for that could be the integration of intercultural training in the curriculum and the overthinking of the preparatory mobility activities as well as closing phases with students' supported self-reflection after the abroad experience.

\section{References}

1. Otten, M. \& Robertson-von Trotha, C. Interkulturelle Kommunikation als Schlüsselqualifikation in der Hochschulbildung: Erfahrungen an der Universität Karlsruhe (TH). In: Mattias Otten, Alexander Scheitza \& Andrea Cnyrim (Hrsg.). Interkulturelle Kompetenz im Wandel, Band 2: Ausbildung, Training und Beratung, Münster: LIT-Verlag. 245 (2009)

2. Bertelsmann Stiftung, Fondazione Cariplo (Hg.) Interkulturelle Kompetenz Schlüsselkompetenz im 21. Jahrhundert? Gütersloh/Mailand: Bertelsmann Stiftung. Retrieved on December 15, 2020)

3. Deardorff, D. Assessing intercultural competence in study abroad students. In: Micael Byram \& Anwei Feng (eds.). Living and Studying abroad, Clevedon: Multilingual Matters. 232 (2006)

4. Jones, E. Internationalization and employability: The role of intercultural experiences in the development of transferable skills. In: Public Money \& Management, 33 (2), 95 (2013)

5. Buchmann, U. \& Huisinga, R. Curriculum research and development. In: Felix Rauner \& Rupert Maclean (eds.). Handbook of Technical and Vocational Education and Training Research, Heidelberg: Springer. 517 (2008)

6. Bolten, J. Grenzen der Ganzheitlichkeit - Konzeptionelle und bildungsorganisatorische Überlegungen zum Thema „Interkulturelle Kompetenz“. In: Erwägen Wissen Ethik (EWE), 14 (3). 157 (2003)

7. Li, Y. Developing intercultural competence on the basis of study abroad experience at the university level. A socio-economic design-based case study, Detmold: Eusl Verlagsgesellschaft. 87 (2017)

8. German Academic Exchange Service/Deutscher Akademischer Austauschdienst (DAAD) (2011). Bachelor und Master auf dem Arbeitsmarkt. Die Sicht deutscher Unternehmen auf Auslandserfahrungen und Qualifikationen, Retrieved on December 14. 56 (2020).

9. Thomas, A. Introduction. In: Alexander Thomas, Eva-Ulrike Kinast \& Sylvia SchrollMachl (eds.). Handbook of Intercultural Communication and Cooperation. Basics and Areas of Application 2nd ed., Göttingen: Vandenhoeck \& Ruprecht, 1.7 (2010) 